\title{
St. Petersburg 2003
}

\author{
By Ron Holloway
}

Fall 2003 Issue of KINEMA

\section{ST. PETERSBURG FESTIVAL OF FESTIVALS}

For much too long, the St. Petersburg Festival of Festivals has lingered in the shadows of the all-mighty Moscow International Film Festival. This year, however, everything has changed for the better. Since 2003 marks the $300^{\text {th }}$ anniversary of the founding of St. Petersburg by Peter the Great, the year has been one long celebration of events and festivals on the Neva. According to some reports, the $11^{\text {th }}$ St. Petersburg Festival of Festivals (23-29 June) under director Alexander Mamontov received as much government funding as did the Moscow International Film Festival (21-30 June) under president Nikita Mikhalkov. Still, it's hard to figure out just why, in this year of national celebration, the calendar dates of the two film festivals should unfortunately overlap each other.

But this is Russia. The same arm-wrestling for calendar position forced the Sochi International and Open Russian Film Festivals (1-14 June) under enlightened programming director Sergei Lavrentiev to open a week after Cannes closed. And since Russian directors and film professionals like to meet on the Black Sea coast to talk business, the Russian competition at Sochi outdistances both Moscow and St. Petersburg so far as measuring the quality of the annual feature film production is concerned. Much the same can be said about the Russian documentaries selected by the St. Petersburg "Message to Man" International Documentary, Short and Animated Film Festival. In fact, this is where the scouts for the Leipzig DOKfestival and the Kiev Molodist (Young Cinema) festivals, both scheduled in mid-October, hang out to select the documentary and animation plums for their respective competitions.

St. Petersburg was particularly generous to guests and journalists who vacated Moscow for the Festival of Festivals. Headquartered in the five-star Corinthia Nevskij Palace Hotel, excursions to the city's cultural sites (Winter Palace, Hermitage Museum) were planned each morning and often for the entire day. The high point of the week was the outing to Peterhof, the pendant to Versailles and Potsdam, with its royal gardens and gold-statue fountains that took eight years to restore at the estimated cost of $\$ 12$ million. Just jump on a speed boat at the wharf before the Hermitage, and you are at Peterhof in 40 minutes.

As for the 100-odd films in the festival program, screened across town at four venues, the screenings of Lars von Trier's Dogville and François Ozon's The Swimming Pool were, of course, major attractions in the large hall at Dom Kino, the festival flagship cinema. But of far greater interest for the local audience was the spectacular nights set aside for the special screening of Alexander Sokurov's Russian Ark, his one-shot review of 400 years of Russian history that was filmed in the Hermitage and Winter Palace, and Otets I syn (Father and Son), winner of the FIPRESCI International Critics Award at this year's Cannes festival. It seemed

like the whole of the city's literary, cultural, and intellectual circle turned out for Father and Son - and saluted their native son afterwards with a standing ovation. Lydia Bobrova, another St. Petersburg director, was honoured with the St. Petersburg Statuette, the Grand Prix of the Festival of Festivals, for Babusya (Granny), a poignant tale of a grandmother who has sacrificed all for her children but is abandoned in her old age by uncaring in-laws.

\section{Author Information}

Ron HOLLOWAY (1933-2009) was an American critic, film historian, filmmaker and correspondent who adopted Europe as his home in the early fifties and spent much of his life in Berlin. He was an expert on the study of German cinema and against all odds produced, with his wife Dorothea, the journal German Film, keeping us up-to-date with the work of directors, producers and writers and the showing of German films around the world.

In 2007, Ron Holloway and his wife were awarded the Berlinale Camera Award. Ron also received the Bundesverdienstkreuz (German Cross of Merit), Polish Rings, Cannes Gold Medaille, the American Cinema 
Foundation Award, the Diploma for Support of Russian Cinema and an honorary award from the German Film Critics' Association.

Ron was also a valued contributor to Kinema for the past fifteen years. 